\title{
FROM SOCIAL MOVEMENTS TO THE COPRODUCTION OF THE CITY: THE RENEWAL OF THE RIGHT TO THE CITY IN THE CONTEMPORARY MAKING OF PUBLIC SPACES. THE CASE OF MADRID AND BRUSSELS
}

\author{
Author(s) / Auteur(s) : \\ Cristina BRASCHI \\ PhD Student \\ Faculté d'architecture, d'ingénierie architecgturale, d'urbanisme (LOCI) \\ Université catholique de Louvain (UCL) \\ Teacher in Urban planning at Académie Royale des Beaux-Arts de Bruxelles \\ cristina.braschi@student.uclouvain.be
}

\begin{abstract}
/résumé :
The article is based on the observation of Madrid and Brussels, where we can find recent similar claims for including each of their citizens in the city-making processes. Although Madrid has no experience in participatory planning, and Brussels is considered as one of Europe's pioneers in this matter, with more than twenty years of experience, both cities encounter analogous citizen demands and self-organized actions for creating spaces that follow an ideal model that is more in line with some citizens' requests.

These demands range from asking for more possibilities in which citizens express their opinion and ideas about their environment (a new governance), to the requests for disposing of underused spaces for creating socializing places to gather (a new production of the city). Though, these urban social movements as Castells defines (Castells 1973) are not limited to mere demands, but also and nowadays systematically, they tend to pass to action and to hand the leading to empowered citizens.

Thanks to crowdfunding, some projects don't even wait until obtaining a public funding: once the building permit is given (for a permanent or temporary project), the budget for the realization comes from anybody who wills to be a sponsor. The online crowdfunding method can be applied also to crowd-thinking, crowd-creating and crowd-debating about the relevance of the project. Indeed, thanks to online networks and to mobile applications, citizens can not only express their discontent with the poor condition of a street or street furniture, but they can also make proposals and connect to other people to bring a collective solution to the matter.

This vast range of means of production of the city in which its citizens struggle to achieve their ideal of a more inclusive city-making process, supposes that the degree of citizen empowerment is also broad. Notwithstanding the fact that the means used by Madrid and Brussels' citizens to be included in the city-making are so diverse, many of these means claim to embrace a common Henri Lefebvre's Right to the City.

The article retraces the citizen-led and citizen-organized production of public spaces in Madrid and Brussels, intended as places to gather but also as places of discussion about the city-making, during the periods before and after the global crisis of 2008. The idea is to find the ways in which not only the governance is reconsidered to include citizens, but also the urban practices are questioned about their inclination to confine citizen participation only to the preliminary inquiries to a concrete project. Through the exploration of several cases of city-making which include citizens of Madrid and Brussels in the processes, the article questions which kind of Right to the city do they constitute: which are the city models defended by these practices (whose rights to what city? Brenner et al. 2012)? Are they a revision of Lefebvre's theories in a (global crisis) context? Or are they a reinterpretation of Lefebvre's Urban Revolution (Harvey 2013) responding to the contemporary withdrawal of the national state of many areas of the social life?
\end{abstract}

\section{Keywords / Mots-clés :}

participatory planning, empowerment, Right to the City, coproduction, public spaces 


\section{BEYOND THE OPPOSITION BOTTOM-UP / TOP-DOWN}

\subsection{From debate to action and vice versa}

Nowadays, it has become evident for many urban planners to understand their practice in a systemic approach that relates planning with policy making, social inclusion and bigger issues instead than conceiving it as a mere spatial development. In this way, urban planning is constituted as a multi-actor system in which the actors are supposed to be included in every part of the negotiations to achieve a consensus or a compromise. But the division of the city-making processes in several separate fields is precisely what enhances the segregation between an elite of different experts (responding about mobility, housing, green areas) and the relegated locals who want to express their ideas in participatory processes but feel overwhelmed by how the process is cryptically presented (supposing this participatory process actually occurs). The analysis of the last forty years of struggles for demanding citizen participation in Madrid and Brussels shows similar evolutions of the different actor interactions and roles, according to an institutionalization of participatory practices. This evolution varies from the demand of the creation of these practices, through the implementation of the methods to achieve a greater number and variety of participants, to the challenging of the concept of participation to include other forms than what is statutory.

Urban activism demanding for the right to interfere in the decisions made by politicians and public administration appears mainly related to demonstrations, debates, and media coverage. But is some occasions, the demand can be accepted, the demonstrations are calmed down and activist demands are included in planning procedures. An eventual institutionalization of the popular assemblies can even occur. Activists who are confronted with starchitects and top-down architectural practices end up demonizing the whole planning procedures as they don't correspond to an ideal of transparence and open city-making. In fact, many good architects from all over the world became known as starchitects because of what was untended as oversized ego: to people, architects seem to contest hearing citizen demands about the project. Nevertheless, this problem was more due to a lack in planning procedures that didn't include participatory processes, than to architect's ego. To the demonization of architects and planners by the activists, the first respond with a shift in their procedures, opening them to a more social perspective, offering their ears to people's demands, through participatory measures. Debates about urban renewal operations are also organized by less protesting groups such as architects willing to broaden the interest for their work, allowing the citizens to express their views about the plans or proposals presented. These debates can even take form of events or festivals to promote the urban renewal plans and call for remarks or proposals. What appears to be less visible is the production of the city by the groups that don't have a clear connection with activism or urban renewal plans, but one way or another they struggle to encompass more urban justice through local actions. These groups have somehow a double heritage: a first one coming from the tradition of anti-authoritarian activism of the seventies and a second one, coming from a more social practice such as advocacy planning. This double heritage produces nowadays a hybrid citizen engagement in which practices are no longer topdown or bottom-up: they are a combination of both.

There is a new portmanteau word for that: co-production. The co-production of the city is a new concept that combines the procedures of a market-driven economy with a multi-actor (intended as public and private stakeholders) for setting up projects of urban renewal. But it can be intended as an opportunity to engage people in the process: empowering them so as they can be involved as an equal part in the negotiations for the setup of the project. In this context, architects can choose to have the role of local projects instigators, fostering citizen empowerment so that people can make proposals, or to limit themselves to the role of mediators, orchestrating the participative process so that it achieves a greater citizen inclusion. This is what we can call today in several manners: Handmade Urbanism, Tactical Urbanism, Co-production of the city, Rebel Urbanism and Radical Urbanism (just to say a few).

In the end, several interpretations of participatory urbanism can be related to one same major fight: preserving and better using the environment as well as having major community engagement. Doing so, these practices (whatever they are called but from the bottom-up or from the mixed perception) 
position themselves against the heritage of Modern Urbanism as a city-changing process (imposing the supremacy of big operations, segregated functions, cities made for cars, superblocks and towers).

\section{FROM SOCIAL MOVEMENTS TO THE COPRODUCTION OF THE CITY}

\subsection{Triggers of the Social Movements in Madrid and Brussels}

The end of World War Two led to a period of urban renewal in many cities of the globe that followed the precepts of Modern Urbanism. Even Spain, who did not participate in this generalized War but was devastated by its own Civil War, conducted big reforms and built infrastructures to reunite the country, mainly between the 50's and the 60's. During the mid-sixties, we can find similar citizen demands in Madrid and Brussels, struggling for a more social production of the city. In Madrid, with the end of the dictatorship approaching from the early seventies, local associations federated to demand the abolition of the authoritarian power and the creation of a social welfare estate that could provide better living conditions to city-center and peripheries' dwellers. The associations also fought against the excessive public intervention in infrastructures, at the expense of the investment in the consolidate city. In Brussels, the citizen association's fights were targeted against the big works for modernization of the city, demanding the return of the traditional city model.

Madrid, as a capital and industrialized city, has been attracting workers from all over the surrounding central Spain, especially after the end of the Civil war in 1939, increasing the number of inadequate housing and public equipment of the city. Despite the modernization of Spain through Franco's infrastructure works, the housing and public equipment popular complains were not totally satisfied by the end of the dictatorship in 1975. The last years of the Franco's dictatorship where characterized by anti-authoritarian struggles, similar to Paris' struggles during May 68' movement, although they were covered by the political context. During this repressed context several local associations were born. Despite the fact that many of these associations were related to the socialist or communist political parties, they had to defend the Right to the city (Lefebvre 1968) through nonpolitically related assemblies (to avoid repression). The end of the dictatorship marked the beginning of the democratic era and the increase of the creation of several local associations. More than twenty local associations were created in those years. Their struggles managed to achieve a well distributed network of public schools, decent housing, public lighting and water, consolidating the informal settlements of the suburbs and the slowing down of the declining city-center.

The Brussels's World Fair in 1958 gave green light to several big projects for high-rise office buildings and car infrastructures such as traffic lanes and parking lots. These big projects were considered as a same and unique process popularly called "brusselization" by its opponents. Brusselization was considered such a specific process that it was treated as if Modern Urbanism had more radical proportions in Brussels than in any other city that followed the precepts of International Style. This transformation period triggered a new critical movement that led to the creation of more than one hundred local committees to fight against evictions related to big projects and to promote urban planning through city reconstruction, following the ideal of compact city. Several of these committees were assembled under the name of Atelier de Recherches et d'Actions Urbaines (ARAU), created in 1969, and Inter Environnement (IEB), created in 1974, still active nowadays.

Local associations in that period struggled to return to the traditional city model, with human dimension (not made only for cars), small and medium housing (not towers) and the preservation of existing patrimony. Their struggles managed to achieve political acceptation of the demands and the inclusion of transparency measures in city-making with the public enquiry prior to every building project, compulsory since 1976. This shift in the urban agenda, was remarked by the architect Jacques Aron, formulating the hypothesis (Aron 1978) of a new turn in Brussel's urbanism practices: the militancy practiced by the quarter committees, ARAU and IEB was no longer against the political power but working as a pair to build the urban agenda. According to Aron, there were two groups of actors working together in the system of the city-making: the group constituted by public administrations + politicians + experts, and the one in which residents gather (temporally or in the long run) for demanding to be heard about the projects for which they feel concerned. 
Despite the political differences, the first period of citizen activism in Madrid and Brussels was marked by the return of the model of the traditional city (after the shaking provoked by International Movement) and the return of the supremacy of the "local" citizen over the newcomer or the simple "user" in the media covered by the activists and local associations. The urban model to be followed was the compact city in which every quarter is self-sufficient in terms of decent housing, public spaces, social and cultural equipment and so on, all provided by the public administration with the agreement of the community.

\subsection{Struggles for citizen participation in Brussels}

Although Participatory Democracy was challenged during the sixties-seventies, arguing that people were henceforth sufficiently informed and active to be included in all the democratic procedures, Participatory Urbanism practices had to wait a little more. The 1998 Aarhus convention, formulated firstly during the Rio Earth Summit in 1992, established the conditions for the participation of the people in the decision-making processes related to the environment, but the translation in local laws of every signatory was subject to different interpretations.

Brussels became a separate Region in 1989, changing the distribution of the urban competencies, from the Federal to the Regional level. With the new distribution, the activism fights recovered more importance, since their demands were directly included by the institutionalized members of ARAU and IEB. The institutionalized activism, fostering a more social and environmental-friendly planning, managed to adapt the environmental laws of the Earth Summit, giving birth to the Quarter Contracts in 1994. These public contracts were established to implement urban renewal in the neighborhoods defined as most in need, with the help of participatory planning. The Quarter Contracts have been evolving since, becoming a model of locally engaged communities, but rising up some critics that questioned to major issues: how to apply them outwards than were they are statutory? And how to include the dispossessed and the deprived (not only well prepared people) in the decision-making?

Parallel to the urban renewal participatory practices, the old patrimony of Brussels was protected and the traditional city promoted. The teachers and students from the architecture schools of Brussels felt somehow, in the one hand, attacked in their competencies about how to deal with patrimony, and in the other hand, misunderstood when trying to give value to Modern architecture such as the Martini Tower built in 1958 and dismantled in the beginning of the two thousands. Thus, some of them started to defend the architectural creativity demanding more room for manoeuver when dealing with complex urban plans and urban renewal proposals. In 1979, the architecture teachers of the School of La Cambre who were close to the philosophy of ARAU were precluded from their teaching practice, leaving the self-called creatives teachers in the school. This event was surnamed the "Affaire de la Cambre", dividing the architecture debate among the activists in one camp, and the partisans of a new turn in architectural practice, in the other camp.

The occupation of the old train station building in Luxemburg Square in Brussels in 1995 (within the area of the European parliament under construction) was more a festive intervention to demand the right for citizens to express themselves about the urban renewal plans (for the European quarter) than the preserving kind of activism led by ARAU and IEB. Several other public debates were organized between 2000 and 2003 to make proposals against the dismantling of the Martini tower, enlarging the pros and cons of Modern Architecture. The architecture activists struggled against the associations ARAU and IEB, criticizing them as passéists or backward-looking. The launching of the debates and campaigns was made by a large group called Disturb constituted by several architects and even some activists from local associations. This kind of open-debate demonstration was defined as a new shift in urban planning by the architect Benoit Moritz: the second turn, referring to Aron's as first turn. The characteristics of this new type of citizen engagement were the open debate, the discussions about the possibilities of architectural creativity, the organization of competitions to have contemporary architecture proposals and a festive nature instead of a demonstrative one. The people engaged in these activities were not only architects but also artists, some local associations for social cohesion, and even people from the administration of cultural centers such as Recyclart. 
The group Disturb gained media coverage in 2003 teaming up with several local associations from Flagey quarter for the organization of the call for ideas for the planning of the Flagey square. The building of a parking and a storm basin underneath the square was supposed to be covered with a simple concrete layer with parking lots. The call for ideas was expected to open the debate about public space renewal in Brussels, focusing in one question: how to achieve a more qualitative design while making the people involve themselves in the planning procedures, giving their ideas? The operation was a success story because the group achieved to make the city council organize a real competition in which the winner had to offer a good design (not only the concrete covering of the area) and engage with the local community in a participatory planning. By the end of the works, the architects were supposed to organize also a community group that will be in charge of the program of activities on the Square. Instead, the Council took the role of the programming. Several local groups of residents of the surroundings still nowadays organize activities on the Square but no purposed group is created to combine a locally empowered community.

By the end of the first decade of the 2000's, Brussels had two ways to enhance citizen participation. The first comes from the legal procedures associated to renewal plans in quarters defined as in need by the EDRLR perimeter (Espace de Développement Renforcé du Logement et de la Rénovation). The second is not meant to be intended as proper citizen participation but as it enlarges the popular debate and seeks for citizen alliance in the demanding for more open procedures (open competitions and collaborative workshops), it could be understood as a new activism that offers a greater Right to the city.

\subsection{Struggles for citizen participation in Madrid}

In Spain, the demonization of architects and their practices didn't come only by activists fighting for preserving their neighborhood: it came by the architects themselves. But these architects were not merely fighting to have more competitions an debates. With the example of the Bilbao effect, every major city in Spain wanted to transform their industry-centered economy into one driven by real estate and tourism. Madrid followed this trend, expanding the land use until doubling the surface of the city but not its population, exceeding the demographic previsions. This growing process was in fact part of a speculation bubble that exploded later on during the 2008 crisis. Facing that, some of the architecture students and teachers of the ETSAM school, decided to promote a more social architecture where the real needs of the population were met, and the end users can even be involved in the building of the projects.

Since creativity and the promotion of architectural and urbanism competitions were not lacking in Madrid's context, the citizen struggle close to the Brussels' case was to enlarge the discussion about urban planning and architecture to include the people in the city-making, instead of giving the project to a renowned group of architects that will not engage in participatory processes. In this sense, the architect Santiago Cirugeda from Sevilla started his career in 1996, inspiring many architecture collectives all over Spain, promoting a hands-on strategy that hacked the urban procedures to make people build their environment according to their desires, with their bare hands. His purpose is also to show young architects and students another way of doing architecture: closer to the people and their concerns, observing their environment, making proposals to be directly built with very little budget and finally not waiting for a competition to "appear" and save their lives. His guerrilla architectural practice proposes urban furniture for occupying boring squares, empty lots and even parking lots. His idea is to empower people to modify their living environment, while giving them another vision of architects (not only starchitects exist) so as people can express in larger urban debates about the reusing of the city through other ways than big renewal plans. The practice of Cirugeda became a sort of urban hack-tivism (as another group from Sevilla calls it: Hackitectura) or even art-ivism, somehow similar to the one developed in Brussels during the late nineties, beginning of the two thousands.

The urban renewal plans in Madrid followed Sevilla's trends: the procedures were applied top-down without public enquiry in such a violent way that not only local associations demonstrated but also architects in line with Cirugeda's views. As an example, the case of the renewal of the Agustin Lara square in Madrid can be paradigmatic. During the late nineties, local associations around the square 
demanded the renewal of the medical center situated in one of the edges of the square. The public administration, facing the degradation and drug-trafficking in the area, decided to renew the square with an underground parking and a stone covering. Despite several demands of the local associations for a more family-friendly planning of the square, the renewal works ended up with no playground and no obstacles to obstruct the view of the police servants. The associations appealed to more socially conscious architects to make a counter-proposal. As a reply to citizen demands, the administration added a marquee for having a shadowed area and stone benches underneath. The whole struggle was documented during the central three years of the process, producing the documentary "A ras del suelo" (at ground level, which could be also understood as from the bottom). No participatory planning was achieved, in contrast with the case of Flagey square in Brussels.

\subsection{The co-production of the city}

In 2001, a group of architecture students from Madrid founded the collective Basurama (contraction from Basura + ama $=$ love your trash), inspired by Cirugeda's new way of opening architecture to a more social practice to foster a larger debate about the reuse of urban resources. Their name was created for a festival organized to think about the renewal of the city through the reuse of its urban voids while rethinking how to have a better management of industrial waste. After seven years of trash-reuse, city-reuse, festivals, and workshops, in 2008 part of the members of Basurama export themselves to South America to explore other ways of community engaging for the "cause" of urban reuse, with the project RUS (Basurama 2011): Residuo Urbano Sólido (solid urban waste). Since this project, several playgrounds have been built in favelas and brownfields allover Latin America.

For the Nuit Blanche 2010 in Madrid, the municipality chose to give Basurama the curatorship role of the event. The group, often in contact with several other groups of architects, artists and empowered citizens, decided to organize a call for proposals to other collectives with the same philosophy to collaborate in the organization of the night event. Some groups who applied to the call decided to focus on the lighting, others on the games people could play, but every project had to have a reflection on how to create spaces for leisure and family-gathering that could become permanent. Thus, the temporary occupation of a $5000 \mathrm{~m}^{2}$ urban void in the city-center during the Nuit Blanche festival, ended up to be an excuse to create what it became Campo de Cebada: a community space where neighbors can gather to play basket, organize theatre events and outdoor screenings, take care of the orchard...etc.

The plot occupied by Campo de Cebada rules under a contract of use with the public administration that owns the site. The contract establishes that the people who manage the place must form a council and have an identified speaker, role taken by Basurama among other collectives. But the place is regularly managed through public assemblies in which everybody is invited to express his/her ideas and make proposals for the programming of the place. Campo de Cebada has thus won several prices (for its design and its management system), it has received media coverage (as an urban experience that challenges the way people can engage in a local community, built their own place and manage it) and has been remarked by the Academia (Erik Swyngedouw 2013) as a symbol of repolitization of the city, and Adam Greenfield (Greenfield 2013 and 2014), as another way to conceive Smart Cities: through Smart Citizens.

On the opposite side of Brussels' model, Madrid did not follow the environmental convention of Aarhus until 2008 with the modification of its Land Act to embody measures of transparency to urban planning. That meant that for more than fifteen years, Madrid was at the back of the pack with regard to participatory planning. Thus, it became a frequent claim for both activists (from the local committees) and for architects (from the art-ivism, festival-philosophy). That constitutes the mayor difference between Madrid and Brussels: in the first, there is no participatory procedures (so the fight is to create the frame for them), and in the second there are the Quarter Committees and a compulsory Public Enquiry but these procedures can't be applied outside specific perimeters and clauses. Despite this difference, and since at least 7 years, in both contexts people, architects and artists federate to rethink planning procedures to empower citizens to achieve a decisive role in the making of the city. 


\subsection{The enhancement of citizen creativity}

After the first decade of the two thousands, the European program for culture changed from "Culture Program 2007-2013" to "Creative Europe 2014-2020": consecrating the beginning of the "creative" reinforcement programs. Since that, both in Madrid and Brussels we have been observing a sort of enhancement of citizen creativity in the promotion of culture.

In 2012, the German Goethe Institute of Berlin chose Madrid for the implementation of a first research about citizen participation and political engagement for urban issues, for a project called participar.de, in collaboration with the Cervantes Institute. This project was conceived as a platform to promote creative views of citizen participation (other than settled planning procedures). Two years later, a new project between the two cities was born: the We Traders travelling exhibition, focusing in the impact of the 2008 crisis on the collectives for citizen participation. Several other cities joined the project, such as Turin, Lisbon and finally Brussels. One city at a time, the local initiatives are presented in a format chosen by the local curators. The venue in Madrid was intended as an opportunity to gather all the citizen collectives that contribute to the city-making: environmentalists (engaged in the urban orchards networks), architects (who build urban devices for citizen empowerment), locals from the citizen associations (who organize festivals and debates about forms that combine Participatory Democracy with revisited citizen participation), etc. The Campo de Cebada was also presented during the venue as a local device that challenges the participatory practices and the way in which public space can be used and managed collectively. The exhibition in Madrid was pointed out by the other cities organizing the event as a quite remarkable because of the organizers' capacity to gather all the local participatory stakeholders in a collaborative production, taking the shape of an open regular debate. One of the explanations for this success is that the different collectives from Madrid knew already each other, forming a network of networks so that they could amplify the call for collaboration, having a bigger impact. This experience has been a trigger for other collaborations between the different collectives in Madrid.

The exhibition in Brussels was also intended to work on a regular basis, gathering people for debate, but it didn't really work. One of the reasons for this flop can be found in the fact that Culture in Brussels is divided in two communities: the Flemish and the French one. Thus, only the collectives that work in the two languages knew each other and started collaborating. But no collaboration is known to be started within the frame of the exhibition.

The exhibition SmartCitizens organized in Madrid during 2013, considered citizen creativity as the producer of a more social city instead of a Smart City. Paisaje Transversal, another collective from Madrid, curated the event making the statement that any city is smart without smart citizens. By doing so, the citizen creativity enhanced by the exhibition was focused principally in ways in which people can organize to compensate or overcome lacks in their everyday life, more than focusing on smart devices. Thus, the selected experiences presented were classified according in the roles people can play in the systemic frame of city-making: as sensors, as informers, as decision-makers, as entrepreneurs. The "sensors" refer to mobile or online devices with which one can demand for the reparation of one's street (such as Fixmystreet). The "informer" role is taken by people who use several devices to inform other how to deal with mobility-related problems (such as MyTaxi to share taxis, or UrbanSteps to know tips about public transportation). The other two roles, "decision-makers" and "entrepreneurs" are quite similar. The first relates to bottom-up approaches and the second also, but with a more decisive perspective, related to a complete co-production of the empowering device. The Campo de Cebada was classified as "entrepreneurship" because it is not only a gathering place; it is understood as a decisive tool for more inclusive negotiations during decision-making processes. In this way, a wide range of cases is exposed, offering a gradation in citizen participation that suits perfectly the different degrees of engagement people could have for the tailoring of their city.

The « Brussels Academy: making the city together » project was created in 2012 to offer free popular education (a sort of training but open to anyone) to urban issues in order to inspire people to involve in the making of the city. During 2015, the theme was Self City, focusing in 5 topics: Little revolutions (how to change the city without completely revolving the system), Reuse-repair-sharing economies 
(for a better use of our objects and urban resources), Mobility (how to deal with the most trafficked city in Europe through other forms of travel), Public Space (collectives producing public space from the bottom-up) and Housing (Community Land Trusts and cooperatives). During the Mobility session, one case related to the concepts of SmartCitizens from Spain, was the one of Velodossier. This citizen initiative asked through crowdfunding to collaborate for the creation of bike lanes in Brussel. The slogan was "Buy yourself a piece of bike lane!" The goal was easily reached but after that, the project could not be realized because of bureaucratic problems. Nowadays, the project is still in research of an issue, to offer way to fund bike lanes and actually create them, without having to wait for the municipality to make them. In the end, many examples could be found in Madrid in Brussels that struggle palliate the contemporary withdrawal of the National State of many areas of the social life.

Another kind of training was created in Brussels in 2007 for the education of members of public administration and planning practitioners, called Pyblik. The training was conceived by some of the people from Disturb association as to complete the planning visions for the public space perspective, considering that there was no vision for how to create vibrant public spaces. Thus, the program created between several architecture schools in Brussels inherited from the second turn of urban planning's philosophy: to open architect's minds (especially those in the administration) to alternative participatory procedures and a more creative vision for public space. Changing the format every three academic years, Pyblik is nowadays constituted by a series of thematic conferences addressed mainly to public administration, but anyone can join.

\section{CONCLUSIONS}

\subsection{Towards a third shift in participatory planning}

With the enhancement of the citizen creativity applied to the city-making, we are assisting nowadays to a novel period in planning that focuses in training. Training of the people, as to give them tools for action, assuring a greater citizen empowerment; and training of the planning practitioners, as to make them adapt to a new era of participative procedures not prescribed by law, more creative and less predictable.

In Spain, the absence of participatory measures triggered the fight of the local associations for the right to express and contribute. In this context, architects have become experts in mediation (between the different stakeholders involved in planning) and in fostering new community projects. Thus, the training offer focuses on popular education for engaging communities, giving examples of urban devices created to allow civic engagement. This new experts in mediation are so many in Spain, that had to aseemble to create a bigger movement. In each city, they create also micro-cartographies to map the struggles that can be related and collaborate. The Do It Yourself Institute, created in 2014 in Matadero (a cultural center in Madrid) looks like a normal exhibition but it is in fact a research-based experience that creates prototypes to be used by activists (such as Occupy Madrid), collectives as Campo de Cebada and so on. In the same line, the Citizen Parliament was created by Zuloark in collaboration with Matadero to build mobile multi-position furniture that invites people to express themselves over political and urban agenda matters. When the idea arrived to Brussels in 2010 through one of the members of Zuloark, it had to be changed and reconsidered so as to meet local demands, and to adapt to a less networked mediators' context. As a conclusion, we could say that Madrid's training is more centered on the people, to foster bottom-up initiatives, than in the architects. Few job perspectives remain for the architects who practice the mediation approach in Spain: they tend to enlarge their practices (consulting, curating, training, research...) as to make a living from this more inclusive philosophy.

In Brussels with the presence of participatory planning laws, the context is divided in two camps: on one side, activists trying to empower people through the education to civic engagement (ARAU School, IEB publications, resident platforms) and on the other side, architects willing to educate the public administrations to open their minds to participatory procedures and architectural creativity. The long experience of the Quarter Contracts (more than twenty years running) has created a body of practitioners specialized in participatory practices. Despite the experience, these stakeholders struggle 
to apply participatory measures outside the heavy-regulated planning frame. These professionals have become the specialists that apply regularly to act as mediators for the many call for community projects organized in Brussels for funding local collective projects (such as Quartiers Verts, for the greening of a quarter). In this context, the Brussels Academy ends up to be centered in the Academia, the activists publications focuses on the residents, the Pyblik training speaks to public administration, and participatory planning experts are relegated to social work.

What is necessary to put in question now is whether the division in Brussels into several citizen initiatives that work separately and trainings that address different stakeholders of the planning process, could be an initial state of what happened in Madrid during the last ten years, of if it is another complete turn on the way planning in made in Brussels. Could it be the third turn?

\section{REFERENCES}

LEFEBVRE, H. (1968/2009) Le Droit à la ville, Paris: Economica Anthropos.

ARON, J. (1978), Le Tournant de l'urbanisme bruxellois. 1958-1978, Bruxelles, Fondation Jacqmotte. BASURAMA, (2011) "RUS: Residuos Urbanos Sólidos/ Basura y Espacio Público en Latinoamérica", Ed. Delirio, Madrid.

SWYNGEDOUW, E. (2013). "Designing the Post-Political City and the Insurgent Polis." Lecture in Cosmopolis, V.U.B University, 22 November 2013.

GREENFIELD, A. (2013) Against the Smart City, e-book: Do Projects.

GREENFIELD, A. (2014) "The Smartest Cities Rely on Citizen Cunning and Unglamorous Technology," The Guardian, December 22, 2014.

MORITZ, B. (2008), Le deuxième tournant de l'urbanisme bruxellois ?, Deuxième colloque urbain interdisciplinaire. UAB Brussels Stadsplatform, 13 juin 2008, Erasmushogeschool Bruxelles.

\section{BIBLIOGRAPHY}

BARNETT, J. (2014) “A Short Guide to 60 of the Newest Urbanisms” pp. 19-21. Issued: April 2014. Retrieved 23 October 2014.

COMHAIRE, G. (2012) "Activisme urbain et politiques architecturales à Bruxelles : le tournant générationnel”, L'Information géographique 2012/3 (Vol. 76), p. 7-23.

DEMEY, T. (1990), Bruxelles. Chronique d'une capitale en chantier. Tome I : Du voûtement de la Senne à la jonction Nord-Midi, CFC-Éditions/Paul Legrain, Bruxelles

DEMEY, T. (1992), vol. II : De l'Expo '58 au siège de la CEE, CFC-Éditions/Paul Legrain, Bruxelles. MCGUIRCK, J. 2014. Radical Cities: Across Latin America in search of a New Architecture. Verso books.

HARVEY, D. (2009) Rebel Cities: from the Right to the City to the Urban revolution. Verso Books.

I.E.B Inter-Environnement Bruxelles (2015) "Urbanisme et luttes urbaines. 41 ans, et alors ?", Bem 274, Bruxelles en Mouvements. Issue : January-February 2015.

JAMAR, D. (2012) “Art-Activisme : enjeux de créativité urbaine à Bruxelles ”, L'Information géographique 2012/3 (Vol. 76), p. 24-35.

LEFEBVRE, H. (1970) La révolution urbaine, Paris: Éditions Gallimard.

NOËL, Françoise (1998), La Ville rapiécée. Les stratégies de la réhabilitation, Bruxelles, PUB.

ROSA, M. and WEILAND, U. (2013) Handmade Urbanism: Mumbai, São Paulo, Istanbul, Mexico City, Cape Town: From Community Initiatives to Participatory Models, Jovis. London.

Various authors, (2005) Les Cahiers de La Cambre Architecture, $\mathrm{n}^{\circ}$ 3, De la participation urbaine. La place Flagey, La Lettre volée/ISACF La Cambre, Bruxelles. 
